\title{
Forventningsafstemning i undervisningen ved brug af modellen for Det konvergente læringsrum
}

\section{- Et studenterperspektiv}

\author{
Lars Peter Bech Kjeldsen, VIA University College \\ Jørgen Bering Asmussen, VIA University College \\ Hanne Wacher Kjærgaard, Aarhus Universitet
}

\begin{abstract}
I en kontekst, hvor studerende generelt får gradvis større indflydelse på afgørende valg i deres uddannelse, ønskede forfatterne i et studenterperspektiv at arbejde videre med anvendelse og brugbarhed af en tidligere udviklet didaktisk refleksionsmodel, Det konvergente læringsrum. Konkret ønskede vi at undersøge, om modellen kunne formidles enkelt i "studenterhøjde" på en sådan måde, at den kunne blive brugbar til forventningsafstemning mellem underviser og studerende. Artiklen beskriver udviklingen af et redskab samt afprøvningen heraf.
\end{abstract}

\section{Engelsk abstract}

In a context where students are given still greater influence on important choices in their education, the authors of this article wanted to continue their work with the application and usability of a previously developed model for pedagogical reflection, The Convergent Learning Space - this time taking the students' perspective. More specifically, we wanted to study whether the model could be presented at "student level" in a way that would make it useful for the balancing of expectations between students and teachers. The article describes the development of a tool for this presentation and the testing of it. 


\section{Indledning og baggrund}

Modellen for Det konvergente læringsrum (DKL) er grundlæggende et forsøg på at beskrive en ny didaktisk praksis og tilhørende refleksion, der er nødvendige, hvis undervisning og læring skal afspejle de nye læringsbetingelser, der omgiver de videregående uddannelser i dag. Disse læringsbetingelser er bl.a. opstået på baggrund af ny teknologi, en udstrækning af læring i tid og rum og en kombination af et nyt syn på de studerendes deltagelse og deres egne forudsætninger 1 .

Den teknologiske udvikling har medført utallige nye muligheder for ny didaktisk praksis i forhold til online læringsmaterialer, virtuel kommunikation, virtuelle netværksbaserede læringsfællesskaber på fx de sociale medier, online produktion og deling på fx YouTube, samt brugergenereret viden på fx Wikipedia (Gynther, 2010). Undersøgelser viser, at netværkssamarbejde og følelsen af deltagelse og ansvar er fremmende for de studerendes motivation og læring (Davidovitch \& Belichenko, 2018; Wang et al., 2013).

Informationer i form af tekster, billeder, videoer etc. eksisterer på flere forskellige platforme (computer, mobil, tablets) og krydser disse platforme uden at være bundet til ét format. Det betyder, at der er adgang til de digitale medier stort set alle vegne, og dette giver nye perspektiver på didaktikkens overvejelser over fx læringsrum, materialer og tilgang til læringsværktøjer (Beetham et al., 2013).

De traditionelle roller hos underviser og studerende ændres i takt med ovenstående, idet underviseren stadig er overordnet didaktisk ansvarlig, men planlægger sit didaktiske design (Asmussen, 2014) ud fra de studerendes grad af frihed i forhold til valg af læringsmaterialer, produktudformning og -indhold, valg af læringsrum etc. (Kjærgaard et al., 2017). De studerende bliver således medansvarlige for deres egen læring og refleksionen over den, det er dem, der arbejder og organiserer, mens underviseren er den stilladsbyggende, der vurderer opfyldelse af delmål samt de mere overordnede mål, som fremgår af studiets beskrivelse.

Projektets overordnede baggrund skal som nævnt findes i forfatternes tidligere arbejde med at udvikle og afprøve modellen for DKL (Kjærgaard et al., 2017, p. 201)som en didaktisk planlægningsmodel for undervisere. Baggrunden for modellen var netop, at den teknologiske udvikling (se fx (McRae, 2015)) gjorde det nødvendigt for undervisere at reflektere over "ansvarsfordelingen" mellem underviseren og de studerende på forskellige parametre.

Da vi i arbejdet med DKL hidtil kun har fokuseret på undervisernes perspektiv, som er forholdsvis velbelyst og viser, at modellen giver dem rigtig god mening og adgang til refleksion over andre aspekter, end de normalt ville inddrage, blev det væsentligt for os at inddrage de studerendes perspektiv, for at modellen kunne bruges som en adgang til at arbejde med forventningsafstemning. Men for at modellen kunne anvendes hertil, måtte dens elementer omsættes til noget, som kan forstås af studerende uden lange teoretiske udredninger, ligesom der måtte udarbejdes et instruktionsmateriale, som kunne facilitere dette ud fra de studerendes præmis.

Baggrunden for at fokusere på de studerende skyldes grundlæggende en antagelse om, at involvering i og indflydelse på undervisningens tilrettelæggelse kan øge motivation, hvilket igen kan føre til et øget læringsudbytte (Dabbagh \& Kitsantas, 2012; Davidovitch \& Belichenko, 2018; Wang et al., 2013).

${ }^{1}$ Se nærmere om DKL i afsnittet Det konvergente læringsrum 


\section{Undersøgelsesspørgsmål}

Denne artikel beskriver således en undersøgelse af, om

1. den tidligere udviklede didaktiske refleksionsmodel, Det konvergente læringsrum (DKL) kan introduceres og gøres forståelig for studerende gennem en studenterdreven formidling.

2. om den i givet fald kan anvendes til forventningsafstemning om frihedsgrader i undervisningen - set fra de studerendes perspektiv.

Modellen er udviklet gennem et aktionsforskningsprojekt og efterfølgende interventionsstudier (Kjærgaard et al., 2017; Kjeldsen et al., 2014).

\section{Metode}

Til at undersøge, om modellen kunne anvendes til forventningsafstemning i et studenterperspektiv, designede vi en pilotafprøvning, som involverede tre grupper: en forskergruppe, en udviklergruppe og en undervisergruppe. Herudover deltog studerende på undervisernes hold. I dette afsnit beskrives deltagere, deres udvælgelse og formatet for pilotafprøvningen.

De to undersøgelsesspørgsmål er nært sammenhørende, da spørgsmålet om, hvorvidt modellen kunne introduceres som gjort her og sikre forståelse, må besvares positivt, for at spørgsmålet om, hvorvidt den er anvendelig, kan besvares meningsfuldt. Det var ikke muligt at komme til at observere de studerende, Lige som det ikke var muligt at interviewe dem, grundet den korte projektperiode, forskellige start- og sluttidspunkter samt stor geografisk spredning, men det vurderedes, at et survey ville kunne producere de data, der var nødvendige til at besvare begge spørgsmålene. Derfor udviklede vi et onlineevalueringsskema, som underviserne bad de studerende besvare ifm. en undervisningsgang.

Mhp. at søge at sikre, at de studerende opnåede tilstrækkelig forståelse af DKL til at kunne arbejde med modellen, valgte vi at entrere med en gruppe studerende, "udviklergruppen", idet vi ønskede et produkt udviklet af studerende, til studerende. Gruppen blev fundet gennem et opslag og en efterfølgende workshop i Studentervæksthuset i VIA, hvor forskergruppen præsenterede deres ideer, og deltagerne arbejdede med muligheder for at omsætte ideerne til et materiale, som kunne tage afsæt i studerendes perspektiv. Tre studerende meldte sig interesserede, og efter at have læst bogen Det konvergente læringsrum (Kjærgaard et al., 2017) mødtes de med forskergruppen for yderligere forståelses- og bebgrebsafklaring ift. projektets mål. Efter dette valgte begge parter at gå videre med samarbejdet.

Udviklergruppen foreslog en app som det mest hensigtsmæssige redskab, en app, som de udviklede konceptuelt i præ-app format. Herudover lavede de følgemateriale i form af introducerende videoer og hjælpetekster.

I app'en, som i afprøvningen havde form af et spørgeskema, skulle de studerende tage stilling til, hvilken frihedsgrad de så som ideel ift. modellens fem elementer (se senere) ift. et konkret, forestående undervisningsforløb. Denne information kunne underviseren derefter få adgang til og inddrage i sin planlægning.

Undervisergruppen blev valgt ud fra forskellige kriterier: involvering af undervisere, som tidligere havde arbejdet med modellen fra et reflekterende underviserperspektiv; involvering af en, som ikke havde deltaget i tidligere afprøvninger. Dette betød, at undervisernes forudsætninger var forskellige. Vi ønskede yderligere at involvere undervisere fra flere af (professionshøjskolens) uddannelser med deres forskellige undervisningstraditioner, hvorfor der blandt de tidligere deltagere blev inviteret en fra de sundhedsfaglige uddannelser (Sygeplejerskeuddannelsen), en fra de pædagogiske uddannelser (Læreruddannelsen) og en fra de teknisk-merkantile uddannelser (Bygningsingeniøruddannelsen). Den 
underviser, som ikke tidligere havde arbejdet med modellen, fik udleveret bogen DKL som forberedelsesmateriale og havde løbende mulighed for at fă vejledning hos medlemmer af Forskergruppen. Undervisergruppen havde naturligvis en rolle i projektet som undervisere, men vi har ikke indsamlet data fra underviserne, da projektets formål her var at tage afsæt i de studerendes perspektiv.

Det skal bemærkes, at de studerendes uddannelsesmæssige baggrund for at tænke med i et pædagogisk eller uddannelsesprojekt er forskellige, dels da læreruddannelsen har et langt større pædagogisk fokus end sygeplejerskeuddannelsen og bygningsingeniøruddannelsen, dels da de medvirkende ingeniørstuderende for en stor dels vedkommende var udenlandske studerende, som ikke var rundet af en dansk uddannelsestradition.

1. Udviklergruppen designede deres pre-app, som forskergruppen kommenterede på, og der blev lavet enkelte justeringer

2. Pre-app'en blev præsenteret for underviserne, som også havde mulighed for at stille spørgsmål. Tids- og arbejdsplan for udvikling og afprøvning blev herefter besluttet - en meget stram tidsplan viste sig nødvendig, da projektet var under tidspres.

3. Underviserne introducerede kort modellen og intentionerne med afprøvningen for deres studerende. 2

4. Underviserne gav deres studerende adgang til det online-videomateriale, som udviklerne havde produceret.

5. Forskergruppen indsamlede data blandt de studerende.

Hele projektet forløb over en periode på 2 måneder.

\section{Det konvergente læringsrum}

I vores definition er DKL "en model, som underviseren kan bruge som refleksionsværktøj i sin planlægning, gennemførelse og evaluering af undervisning og læring” (Kjærgaard et al., 2017, p. 18). DKL omfatter fem elementer, som vi har arbejdet med at gøre anvendelige og meningsfulde i relation til såvel samfunds- som uddannelsesudviklingerne og underviseres forståelse og praksis. Helt grundlæggende tager vores arbejde udgangspunkt i en forståelse af læring som socialt situeret (Lave \& Wenger, 2004), konstrueret og medieret (Vygotskij, 1978); og en forståelse af, at læring handler om betydningsdannelse hos den enkelte studerende (Kress, 2010), hvis udgangspunkt derfor nødvendigvis må involveres i underviserens planlægning. Det har vi søgt at gøre ved at sætte fokus på fem elementer, som ikke indgår i de gængse didaktiske planlægningsmodeller, men som er blevet aktualiseret af udvikling og udbredelse af teknologi i uddannelsessystemet og samfundet i det hele taget (McRae, 2015).

\section{Elementerne}

De fem elementer, vi gennem aktionsforskning, tilretning og intervention har fundet betydende (Kjeldsen et al., 2014; Kjeldsen \& Kjærgaard, 2016), er:

\footnotetext{
${ }^{2}$ Et hold studerende (LU) havde dog tidligere arbejdet med modellen i studiet ift. deres udvikling til lærere.
} 
* Læringsrum - som defineres dels som de traditionelt beskrevne (Kjeldsen \& Jensen, 2010; Prinds, 1999), dels som en udvidelse af disse med det digitale (Kjeldsen et al., 2014)

* Læringstilgang - som omfatter begreber som didaktisk design (Levinsen \& Sørensen, 2014) og dermed også bliver udgangspunkt for flere af de andre elementer

* Læringsværktøjer - som omfatter den hardware, de undervisningsmaterialer, teknologier, apps, webtjenester m.m., som kan være relevante i og for undervisningen

* Livsverden - som er de(n enkelte) studerendes "mentale baggage af levet liv, erfaring, holdning, livsanskuelse [...] etc.” (Kjærgaard et al., 2017, p. 60)

* Tilgængelighed - som omfatter dels fysisk og økonomisk tilgængelighed af læringsværktøjer og -ressourcer, men i høj grad også inkluderer viden om og kompetencer ift. brug af disse - både hos underviser og studerende.

Modellen har som sit helt centrale udgangspunkt, at underviseren ift. de fem elementer skal overveje, i hvilken grad vedkommende vil beslutte, fx hvilke læringsværktøjer og læringsrum, der skal benyttes, og i hvilken grad han/hun vil lade de studerende have valgfrihed. Der er således for hvert element tale om et kontinuum som illustreret nedenfor:

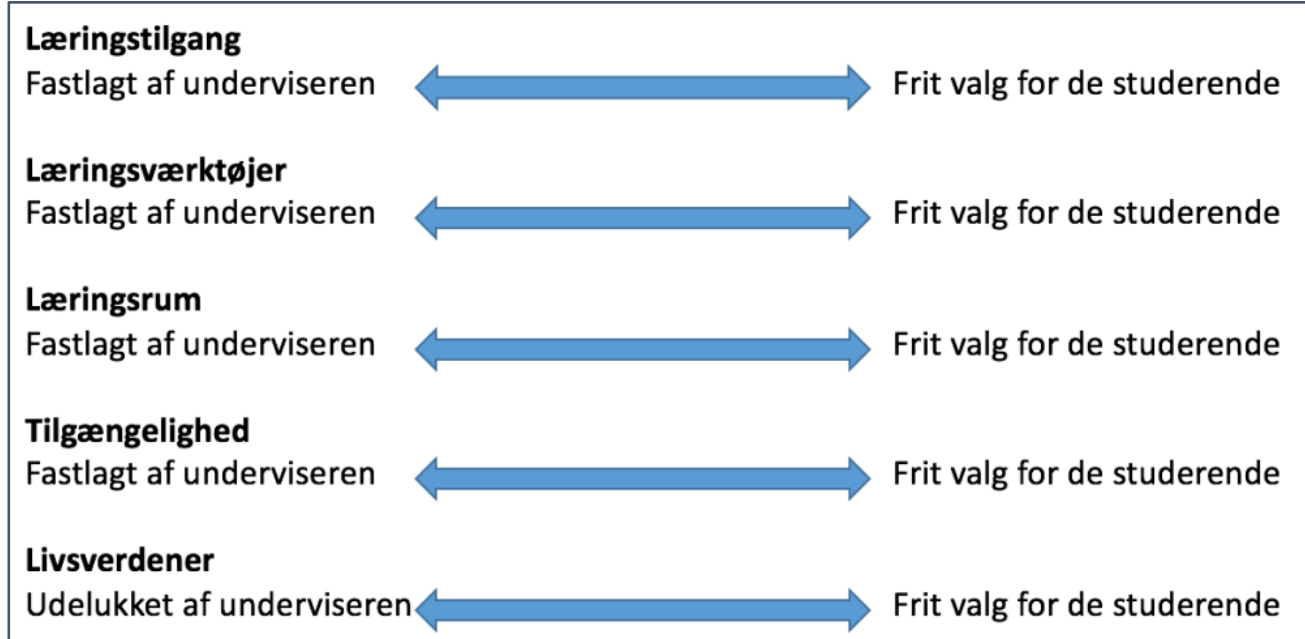

Figur 1: Modellens fem kontinua (Kjærgaard et al., 2017, p. 70)

\section{Forventningsafstemning og anvendelse af modellen for DKL}

En søgning i den internationale litteratur giver stort set ingen resultater på begreber som forventningsafstemning, pædagogisk kontrakt o. lign. i en skolastisk læringskontekst uden for Skandinavien. Dette skyldes givetvis, at der er en særlig tilgang til læring i Skandinavien, hvor der er en interesse for inddragelse af de studerende i undervisningen og tilrettelæggelsen heraf. Dette er årsagen til, at den litteratur, der henvises til i det følgende, er fra de nordiske lande og samtidig ikke beror på egentlig forskning, idet fænomenet pædagogisk kontrakt ikke er væsentligt belyst. Når vi alligevel medtager det her, er det fordi, det netop angiver en kendt kontekst for forventningsafstemning i Danmark.

Formålet med en forventningsafstemning i en pædagogisk kontekst er grundlæggende at bringe undervisere og studerende tættere på hinanden for at opnå optimale læringsbetingelser, hvor underviseren dels har mulighed for at fokusere på de studerendes konkrete læringsmål, dels har mulighed for at stilladsere de studerendes læringsarbejde. Et andet forhold er, om forventningsafstemningen kan bero på ægte frivillighed, idet der er et asymmetrisk magtforhold mellem underviser og studerende. Dels har underviseren ansvaret for undervisningens indhold, dels ansvaret for at indfri de institutionelle og 
organisatoriske krav til undervisningen fx om brug af digital læringsplatform. Asymmetrien er reel, men som en undersøgelse peger på, er de studerende dog ikke helt magtesløse i relationen:

"Studentgruppen är inte ett maktlöst offer i en asymmetrisk situation där de är underordnade lärargruppens krav. De har inte bara sin "voice", genom de krav de kan ställa på lärarna, kurslitteraturen, undervisningens inriktning och förläggning; de har också en "exit"-möjlighet" (Olofsson, 2013, p. 53). Yderligere kan man tilføje, at selv om det overordnet er underviseren, der har 'magten' til at udstikke de store linjer i relation til studiets bestemmelser, har den studerende ansvar for delprocesser, delmål, værktøjer osv. og er derfor ikke sat helt uden for magten. En forventningsafstemning mellem underviser og studerende, hvor præmisserne er væsensforskellige for de to parter qua deres roller som hhv. underviser og studerende.

En svensk undersøgelse er nået frem til samme konklusion vedrørende grundlaget for den pædagogiske kontrakt:

\footnotetext{
"Det som våra fallstudier av en rad olika undervisningsprogram ... visar är hur kontraktets premisser etableras, förmedlas och delas mellan parterna, parter som i sig snabbt förändras på grund av att det ständigt kommer nya lärare och nya studenter. Det är således samspelet mellan förväntningar, förhållningssätt, (för)handlingar och en fixerad institutionell form som är det centrala i begreppet." (Olofsson, 2013, p. 54)
}

Den gode forventningsafstemning, der tager højde for de studerendes præferencer ift. valgfrihed, fordrer, at underviseren grundlæggende og reelt er indstillet på at inddrage de studerende i undervisningsplanlægningen. Underviseren må indtage en rolle ift. de studerende, hvor vedkommende betragter dem som ligeværdige ift. at træffe beslutninger om, deres læringspræferencer i forskellige læringssituationer. Det er samtidig et krav, at underviseren på baggrund af de studerendes individuelle refleksioner forsøger at designe det forløb, der matcher klassens samlede profil bedst. Ved præsentationen af undervisningsplanen må underviseren eksplicitere sine overvejelser over valget over for de studerende og samtidig under denne forventningsafstemning været indstillet på yderligere justeringer af planen. Samtidig står det klart, at underviseren har det overordnede didaktiske ansvar og overblik.

\section{De studerende og forventningsafstemning}

Arbejdet med en forventningsafstemning, baseret på DKL's elementer, stiller nogle krav til den studerende; krav, der er med til at definere den rolle, som den studerende indtager ift. underviseren og de medstuderende. Trods det asymmetriske forhold mellem underviser og studerende, skal de studerende være indstillet på individuelt at eksplicitere deres læringspræferencer for underviseren.

Den konkrete forventningsafstemning sker i det øjeblik, underviseren præsenterer sin undervisningsplan baseret på en opsamling af de studerendes individuelle beskrivelse af deres læringspræferencer. Denne undervisningsplan skal samtidig tage afsæt i formålet med undervisningen og studieordningens beskrivelser af forløbet. Her er det den studerendes rolle at forholde sig til og tage stilling til, hvorledes undervisningsplanen matcher egne læringspræferencer og dermed de muligheder eller begrænsninger, planen skaber for vedkommende. Her må den studerende på et vist niveau acceptere, at 'man ikke altid kan få det, man gerne vil', men at den forventningsafstemning, der finder sted ift. den konkrete undervisning gør, at der er et bedre match med de studerendes præferencer, end hvis en bevidst refleksion over modellens 5 elementer, dvs. egne læringspræferencer, ikke havde fundet sted, og underviseren $i k k e$ havde haft kendskab til disse. 


\section{Datagrundlag}

De studerendes svar på forskergruppens online-evalueringsskema udgør datagrundlaget for rapporten ${ }_{3}$, som indeholdt såvel lukkede som åbne spørgsmål. Data er således både kvantitative og kvalitative (Franklin, 2012). Skemaet blev distribueret til 82 studerende gennem selvoprettelse via link (SurveyXact). Af disse har 37 gennemført, 36 har besvaret delvist, mens 9 ikke har angivet nogen svar. Det skal bemærkes, at alle personer er anonymiserede og angives i materialet her med et $\mathrm{M}$ eller $\mathrm{K}$ for mand eller kvinde og et løbenummer, fx M42, K43.

Svarene fra de respondenter, der kun har besvaret delvist, men som har afgivet meningsfulde svar og ikke blot skrevet tilfældige bogstaver, er medtaget. Derudover var det nødvendigt at lave en inddeling af respondenter ud fra andre kriterier, nemlig om svarene kunne kategoriseres som "ugyldige", da de enten indeholdt tilfældige bogstaver, de studerende havde svaret "ved ikke" til alle spørgsmål, eller havde angivet ikke at have været til stede, da modellen blev introduceret.

Dermed er der i alt 31 respondenter tilbage, hvis svar medtages. Fordelingen af og opgørelsen over respondenter ses i tabellerne nedenfor:

Tabel 1: Andelen af gyldige, ugyldige og manglende svar

\begin{tabular}{|l|l|}
\hline Svar & Respondenter \\
\hline Gyldige svar & $31(37,80$ pct.) \\
\hline Ugyldige svar & $12(14,63$ pct.) \\
\hline Manglende svar & $39(41,56$ pct. $)$ \\
\hline I ALT & $82(100$ pct.) \\
\hline
\end{tabular}

Tabel 2:Sprogfordeling blandt gyldige svar

\begin{tabular}{|l|l|}
\hline Sprog & Respondenter (gyldige svar) \\
\hline Engelsk & $18(58,06$ pct.) \\
\hline Dansk & $13(41,94$ pct.) \\
\hline I ALT & 31 (100 pct.) \\
\hline
\end{tabular}

Af hensyn til analysen viste det sig nødvendigt igen at underinddele de gyldige svar:

${ }_{3}$ Talmateriale m.v. findes i (Asmussen et al., 2019). 
* Nogle svar kunne kategoriseres som uanvendelige, da de ikke var udtryk for et reelt svar på det stillede spørgsmål, $\mathrm{fx}$ i form af, at respondenten har angivet ikke at have forstået spørgsmålet eller ikke husker noget, som tillader ham/hende at svare.

* De resterende anvendelige svar, blev derudover inddelt i unuancerede, fx bare et ja eller nej, og i nuancerede, dvs. svar, som ud over fx ja/nej kommer med en uddybende eller nuancerende forklaring. Eksempler herpå gives i de enkelte analyseafsnit.

\section{Analyse}

Det bemærkes, at vi i analysen overvejende medtager anvendelige, nuancerede svar, således som disse blev defineret ovenfor.

\section{Undersøgelsesspørgsmål 1: Kan Det konvergente læringsrum (DKL) introduceres og gøres anvendelig/forståelig for studerende gennem en studenterdreven formidling?}

\section{Instruktionsmaterialerne}

Som nævnt indeholdt app'en studenterproduceret instruktionsmateriale i form af video og hjælpetekster, og vi vælger at indlede med at se på instruktionsmaterialerne og de studerendes oplevelse af disse som hjælp til forståelse af DKL, som dette blev søgt afdækket gennem seks spørgsmål i spørgeskemaet.

\section{Spørgsmål 1: Har beskrivelsen af elementerne været tilstrækkelige til, at du kunne anvende dem?}

Til dette spørgsmål var der seks anvendelige, nuancerede svar, hvor de studerende kommenterer og reflekterer over instruktionsmaterialernes introduktion til modellen, fx med svar som "Modellen var tilstrækkelig at anvende, men de forskellige elementer skal [beskrives] tydeligere"(M96).

Flere angiver, at især videomaterialet var en stor hjælp, men begreberne har været abstrakte og svært forståelige for flere, fx "... oplevede det for abstrakt og for lidt konkret..." (M2O), mens en studerende også angiver at have haft gavn af beskrivelserne: "De har været i orden, lidt svært med begreberne, men ved lidt hurtig tænkning, så gav det nu meget god mening" (K98).

\section{Spørgsmål 2: Har hjælpeteksterne hjulpet dig ift. at vælge frihedsgrad på de fem elementer?}

Det skal nævnes, at de unuancerede svar på dette spørgsmål i overvejende grad er negative (ni over for tre positive). De studerende, som har afgivet andet end unuancerede ja/nej-svar kommenterer, at hjælpeteksterne "... besvarede mange af de spørgsmål, der dukkede op ved arbejdet med modellen" (M92) og "Yes, they made those questions easier to understand" (K1O4). Det lader til, at for bl.a. disse studerende fungerede materialet som en hjælp til forståelsen.

\section{Spørgsmål 3: Har videoerne hjulpet dig til at vælge frihedsgrad på de fem elementer?}

Det skal her nævnes, at de unuancerede ja/nej-svar her er mere ligeligt fordelt, og de nuancerede svar viser overvejende positive tilkendegivelser, fx: "Ja, jeg synes videoerne var gode, hvor der var gode forklaringer, så man var mere afklaret med, hvad man skulle gøre" (M37). Der var dog også studerende, som ikke havde fundet hjælp i videoen: "Not to a significant extent" (K139).

Spørgsmål 4 \& 5 Var der et af elementerne, hvor det var særlig let at sætte et kryds? Hvorfor? Var der et af elementerne, hvor det var særlig svært at sætte et kryds? Hvorfor? 
De studerendes svar på disse spørgsmål tyder ikke på, at der er noget element, som har været generelt lettere eller sværere at forholde sig til; flere angav læringsværktøjer - dog både som det letteste og det sværeste - mens andre mener, tilgængelighed var lettest. Der var flest studerende, som kommenterede, hvad der var lettest, mens kun ganske fă kommenterede hvad der var det sværeste, fx "Livsverden, fordi: hvor relevant er det? Forstod i første øjekast ikke hvad det var” (M96).

\section{Generelle kommentarer}

De studerende kunne yderligere komme med mere generelle kommentarer via spørgsmålet: Andre kommentarer til arbejdet med elementerne?

I disse kommentarer ses en del svar, som siger noget om de studerendes oplevelse af deres arbejdet med modellen. Flere angiver, at introduktionen ikke havde været tilstrækkelig til, at de kunne forstå og anvende modellen, fx: "Vi skulle have gennemgået dem [elementerne] inden undervisningen" (M26) og "If we could have watched the video again and maybe had some more instruction [...] it could be more useful" (M123). Andre forholder sig mere reflekterende og siger fx: "Lige i første øjeblik ser det ud som om, det er let at arbejde med at sætte en værdi på de 5 elementer, men hvis man begynder at arbejde med dem, bliver det svært fordi der netop er den store frihedsgrad” (K91).

Overordnet set angiver de studerende dog, at introduktionen til modellen ikke har været tilstrækkelig til at sikre dem den nødvendige forståelse, således at den reelt har kunnet få indflydelse på deres læreproces. En studerende angiver at have oplevet en overførselsværdi, og dermed må det antages, at denne studerende har forstået modellen: "Det var godt at arbejde med Spider web4. Jeg lærte det at man automatisk benytter sig af en mindre form for Spider web model når man skal bruge en opgave fra fx Clio (M96). Endelig er der én studerende, som tilsyneladende har opnået passende forståelse af modellen som et redskab til at skabe refleksion over egne præferencer for læringsbetingelser i et digitalt perspektiv: " ... det gav en fin tilgang til vores forståelse af, hvordan man kan tilgå undervisningsmaterialer i et online perspektiv" (M92).

Vi kan derfor ikke konkludere, at materialerne har været tilstrækkelige til at gøre modellen fuldt forståelig for de studerende, men samtidig er der eksempler på, at det har været tilstrækkeligt for nogle studerende.

\section{Undersøgelsesspørgsmål 2: Kan DKL anvendes til forventningsafstemning om frihedsgrader $i$ undervisningen - set fra de studerendes perspektiv}

De studerendes oplevelse af at kunne angive ønske vedr. frihedsgrader og anvendeligheden af modellen som hjælp til deres refleksion blev søgt afklaret gennem to spørgsmål:

\section{Spørgsmål 1: Hvordan har det været at skulle vælge frihedsgrad på de fem elementer?}

De studerende afgiver her overvejende positive svar, fx: "it gave me the opportunity to express my thoughts. Overall, good experience" (K103) og "Det har været rart at have indflydelse på undervisningen” (M28). Der er dog også en enkelt (M93), som angiver at der har manglet begrænsninger, lige som en studerende ikke har kunnet angive sin præference men har "put trust in the teacher that she knew better in some way" (M111).

${ }^{4}$ Den visualiseringsmodel, som blev anvendt - se (Kjærgaard et al., 2017, p. 73). 
De studerende blev gennem følgende spørgsmål spurgt om deres oplevelse af betydningen af forventningsafstemningen:

Spørgsmål 2: Har det været fremmende for dit udbytte af undervisningen, at du har forventningsafstemt dine egne muligheder for at vælge frihedsgrad ift. de enkelte elementer?

Her ses nok det mest positive aspekt ved undersøgelsen, da 10 studerende nuancerer deres oplevelse af, at arbejdet med værktøjet har haft en betydning for dem ift. valgfrihed, indflydelse og øget refleksion over læringstilgang. De svarer fx: "Det har været udfordrende og derved også krævet en anden tilgang end normalt, hvilket jeg har kunnet hente refleksiv anvendelse fra" (M92). Andre taler om det positive i indflydelse (M93), i det at kunne "snakke om, hvordan det kan komme til at fungere bedst for alle" (M98). Dog skorter det stadig på tilstrækkelig forståelse, som det ses af: "Again, I think the idea is very good, but to really make a difference, I think the students need a better understanding of the elements" (K122).

De studerende, som angav anvendelige og nuancerede svar ift. app'ens beskrivelser af elementerne, forholder sig til modellens anvendelighed og tilgængelighed. Disse studerende forholder sig refleksivt og konstruktivt til modellen, men er delte, ift. om de vurderer den som positiv. Især videoerne opfattes positivt. Samtidig ønsker de mere støtte og forklaring, især ift. at holde de fem elementer ude fra hinanden. Flere taler positivt om app'ens hjælpetekster som noget, der har hjulpet deres forstålse og antageligvis også højnet deres læringsudbytte.

\section{Konklusion}

Målet med pilotafprøvningen var at belyse de to undersøgelsesspørgsmål.

Ser vi først på, hvad der kan konkluderes på baggrund af undersøgelsesspørgsmål 1 (opnåelse af forståelse gennem studenterproducerede materialer), så vurderer de studerende hjælpeteksternes anvendelighed forskelligt, idet en del tilkendegiver, at teksterne ikke har hjulpet dem, mens fire angiver, at teksterne har givet dem en større forståelse for spørgsmålene. De engelsktalende studerende giver i nogle tilfælde udtryk for manglende generel forståelse, men det kan ikke konkluderes, om dette skyldes hjælpeteksternes sproglige tilgængelighed, eller om der er tale om manglende forståelse for DKL som sådan.

Instruktionsvideoerne vurderes på lignende måde, da flertallet ikke synes, at de har hjulpet på forståelsen, mens 5 studerende har haft glæde af dem. Det kan altså ikke konkluderes, at videoerne generelt har understøttet de studerendes forståelse, og de karakteriseres både som fremmende for forståelsen og som forvirrende. Det fremgår også her af de engelske studerendes besvarelser, at der har været visse forståelsesproblemer, som kan være af sproglig karakter, eller som kan stamme fra manglende forståelse af indholdet i DKL.

Til spørgsmål vedr. modellens tilgængelighed - lette og svære valg - viser de studerendes svar, at de har kunnet reflektere over hvor hhv. let og svært det var at anvende de enkelte elementer, men svarene peger ikke på et entydigt billede af, hvilket element der var hhv. lettest og sværest at anvende. Det er dog tydeligt, at flest har kunnet udtale sig om, hvilket element der var lettest at anvende.

Ser vi dernæst på undersøgelsesspørgsmål 2 (modellens anvendelighed), så beskriver nogle studerende med forskellige personlige begrundelser, at de godt kunne lide arbejdet med modellen, eller at de syntes, det var en god ide, at det gav plads til egne tanker, og at det var tilfredsstillende, at underviseren kunne give plads til individuelle valg. 
Selv om det ikke er denne artikels primære ærinde at diskutere modellens betydning for de studerendes læringsudbytte så rummede evalueringen også spørgsmål om dette. Her var de studerendes svar nogenlunde ligeligt fordelt mellem positive vurderinger af valgfrihedens læringsfremmende muligheder og mere forbeholdne tilkendegivelser, der med forskellige begrundelser ikke tillægger introduktionen og arbejdet med DKL nogen indflydelse på deres læring. De positivt indstillede peger på, at valgfrihed og indflydelse har haft en betydning for deres læring, samt at det har givet anledning til refleksion over læringstilgang.

Det er således på baggrund af denne undersøgelse ikke muligt at sige noget entydigt om betydningen af at arbejde med DKL ift. forventningsafstemning pba. materialer udviklet $a f$ studerende, til studerende. Dog synes de studerendes arbejde med modellen i et vist omfang at afstedkomme refleksion over deres læringspraksis.

\section{Perspektiv}

Vi kan overordnet se, at det vil være nødvendigt at arbejde videre med modellens anvendelse som værktøj for studerende og underviseres forventningsafstemning, da det lader til, at der er behov for en grundigere introduktion end den, der blev givet. Et perspektiv vil være, at give de studerende mulighed for gentagne gange at vende tilbage til instruktionsmaterialerne, således at de undervejs kan opfriske deres viden om de enkelte elementer, ligesom det vil være hensigtsmæssigt, at modellen bliver anvendt jævnligt af de studerede og i flere fag samtidig.

I vores arbejde med udvikling af DKL har adskillige undervisere fra forskellige uddannelser været inddraget i afprøvning af DKL-modellen og dens didaktiske idegrundlag (Kjærgaard et al., 2017), og disse undervisere har givet mange udtryk for, at arbejdet med modellen har været et gennembrud for dem i deres didaktiske forståelse og planlægning. Dette gælder især uddannelser med tradition for en mere instruerende undervisningstilgang, men også fx læreruddannelsens undervisere, der har et 'indbygget' didaktisk fokus, udtrykker tilfredshed med modellens støtte til refleksion over en ny didaktisk praksis. Med baggrund i ovennævnte praksisafprøvning ser det ud til, at de studerende ud over en app også har brug for introduktion fra underviserne - og denne kræver, at underviserne har en rimelig grad af parathed, hvis intentionerne bag DKL skal lykkes fuldt ud. Støtte af undervisernes forståelse kan fx ske gennem tilbud om en samlet kursuspakke, hvor underviserne får grundig orientering med introduktion til teorigrundlag og med forslag til anvendelse i praksis med de studerende.

\section{Referencer}

Asmussen, J. (Ed.). (2014). Didaktisk design i dansk: Digital planlægning og praksis (1. udgave). Hans Reitzel. https://www.statsbiblioteket.dk/au/\#/search?query=recordID\%3A\%22sb_6044340\%22

Asmussen, J., Kjeldsen, L. P. B., \& Kjærgaard, H. W. (2019). Rapport om pilotprojekt: Afprøuning af Det konvergente læringsrum til forventningsafstemning med studerende.

Beetham, H., Conole, G., de Freitas, S., Ellaway, R. H., Jones, C., Masterman, L., Pegler, C. R., Sharpe, R., \& Traxler, J. (2013). Designing for Learning in an uncertain Future. In H. Beetham \& R. Sharpe (Eds.), Rethinking Pedagogy for a Digital Age: Designing for 21st Century Learning (p. 258).

Dabbagh, N., \& Kitsantas, A. (2012). Personal Learning Environments, social media, and self-regulated learning: A natural formula for connecting formal and informal learning. The Internet and Higher Education, 15(1), 38.

Davidovitch, N., \& Belichenko, M. (2018). Facebook Tools and Digital Learning Achievements in Higher Education. Journal of Education and E-Learning Research, 5(1), 8-14.

Franklin, M. (2012). Understanding research: Coping with the quantitative - qualitative divide. Routledge.

Gynther, K. (2010). Didaktik 2.o. Læremiddelkultur Mellem Tradition Og Innovation. Didaktikserien. Akademisk Forlag.

Kjærgaard, H. W., Asmussen, J., \& Kjeldsen, L. P. B. (2017). Det konvergente læringsrum. Klim. 
Kjeldsen, L. P. B., \& Jensen, J.-O., f. 1968. (2010). Krop og kommunikation i skolen: Begreb om relationskompetence. Århus Kommune, Børn og Unge.

Kjeldsen, L. P. B., \& Kjærgaard, H. W. (2016). A MODEL THAT ALLOWS TEACHERS TO REFLECT ON THEIR ICT APPROACHES : THE CONVERGENT LEARNING SPACE. INTED2016 Proceedings. https://www.statsbiblioteket.dk/au/\#/search?query=recordID\%3A\%22sb_pure_ddfmxd\%3A1c69eo7f-e8b942dd-ac53-dfabcbfaf6f8\%22

Kjeldsen, L. P. B., Kjaergaard, H. W., \& Asmussen, J. B. (2014). Det Konvergente LæringsrumForskningsrapport. Unpublished.

Kress, G. R. (2010). Multimodality: A social semiotic approach to contemporary communication. Routledge.

Lave, J., \& Wenger, E. (2004). Situeret læring og andre tekster, 2. Oplag. Lave, Jean \& Wenger, Etienne (2004). Situeret Læring Og Andre Tekster, 2.

Levinsen, K. T., \& Sørensen, B. H. (2014). Didaktisk design-digitale læreprocesser. Lindhardt og Ringhof.

McRae, L. (2015). Teaching in an Age of Ubiquitous Computing: A Decelerated Curriculum. Digital Culture \& Education, 7.

http://search.ebscohost.com/login.aspx?direct=true\&profile=ehost\&scope $=$ site\&authtype $=$ crawler\&jrnl=183 68301\&AN=110123216\&h=tWhQa7fgWCY547YldKDjng7jHfCovQgFcBl9sa4SC74OoUEIbgnTA6Y75drHLZVp TZvZ76Ley\%2BhFoqH59kJMxQ\%3D\%3D\&crl=c

Olofsson, G. (2013). Utbildningskontraktet. In E. Fasth \& G. Olofsson (Eds.), Studenterna och deras utbildningar vid ett nytt universitet. Ariadne förlag.

Prinds, E. (1999). Rum til læring. Center for Teknologistøttet uddannelse.

Vygotskij, L. S. (1978). Mind in society: The development of higher psychological processes (M. Cole, Ed.). Harvard University Press.

Wang, J., Yu, W.-C. W., \& Wu, E. (2013). Empowering Mobile Assisted Social E-Learning:" Students' Expectations and Perceptions". World Journal of Education, 3(2), 59-70. 


\section{Forfattere}

\section{Lars Peter Bech Kjeldsen}

Forsknings- og Udviklingschef, ph.d., Forskningscenter for Sundhed og Velfærdsteknologi, VIA University College

Har i en årrække forholdt mig aktivt til teknologiens udvikling på det uddannelsesmæssige område. Har gennem forsknings- og udviklingsarbejder samt forfattervirksomhed arbejdet med følgende temaer: Læring og vejledning i virtuelle læringsmiljøer samt videndeling og kommunikation gennem digitale medier.

\section{Hanne Wacher Kjærgaard}

Centerleder, cand. phil., ph.d., Det Nationale Center for Fremmedsprog, Aarhus Universitet

Tidligere leder af VIAs Center for E-læring og Medier. Har i mange år arbejdet med it og læring i mange sammenhænge samt arbejdet med it og feedback i sprogundervisningen

\section{Jørgen Bering Asmussen}

Lektor, cand. Mag., VIA University College

Udgivet lærebøger om it-didaktik, medier, it i danskfaget mv. Forfatter til rapporter og udviklingsarbejder om medieanalyse, mediedidaktik og medieproduktion i læreruddannelsen
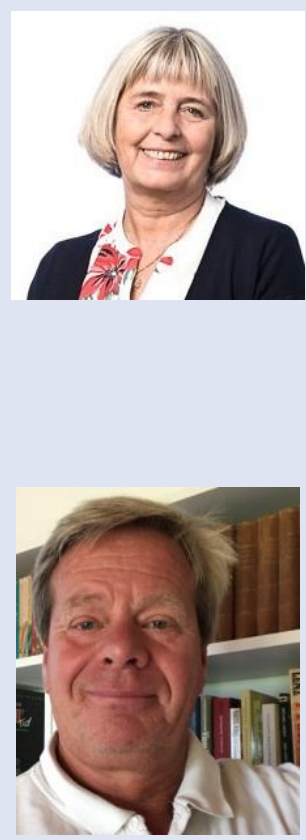